\title{
Prospects for using Sprinkler Irrigation for Carrots (Daucus carota L.) in the Foothills of South-east Kazakhstan
}

\author{
Dinara Seidazimova ${ }^{1}$, Temirzhan Aitbayev ${ }^{2}$, Levente Hufnagel ${ }^{3}$, \\ Gulfaridat Kampitova $^{1}$ and Birzhan Rakhymzhanov ${ }^{2}$
}

\author{
${ }^{1}$ Kazakh National Agrarian University, Kazakhstan, 050010, Almaty, Abay Avenue, 8 \\ ${ }^{2}$ Kazakh Scientific-Research Institute of Potato and Vegetable Growing, \\ Kazakhstan, 040917, Kaynar, Nauryz St. 1. \\ ${ }^{3}$ Szent István University, Hungary, H-2100 Gödöllõ, Páter Károly u.1
}

http://dx.doi.org/10.13005/bbra/2081

(Received: 11 April 2016; accepted: 04 June 2016)

\begin{abstract}
The soil and climatic conditions of south-east Kazakhstan are favorable for growing sufficient amounts of agricultural crops, including vegetables. Kazakhstan was on the bottom line in terms of water supply among the post-Soviet countries before it became an independent state. Therefore, among recent tendencies there is a shortage of irrigation water and worsening of soil fertility mostly associated with global warming/ climate change, and as a consequence of the irrigation systems' destruction during the period of changes. Consequently, such issues encourage agricultural scientists to investigate and adapt water-saving technologies to the local soil and climatic conditions. These technologies allow water saving and protect the soil from erosion due to irrigation, as well as increasing the productivity of agricultural crops of particular vegetables. Thus, in the conditions of the south-east Kazakhstan several studies have been conducted to evaluate the sprinkler irrigation system (finely dispersed irrigation) for carrots. The aim of this paper is to assess the effect of sprinkler irrigation on the water consumption of the carrot crop, contamination of the fields, yield and quality of the product. It has been established that finely dispersed irrigation (sprinkler irrigation) helps to conserve irrigation water by $18.44 \%$ on the carrot sowings compared to traditional method of watering. Moreover, sprinkler irrigation contributed to higher yields of the carrot, improved the product quality and led to the reduction of the field contamination.
\end{abstract}

Keywords: carrot, sprinkler irrigation, crop yield,

field contamination, product quality, south-east Kazakhstan.

Generally, sometimes we do not think about what benefits we get from vegetables in our daily diet. Since ancient times, vegetables have been used in food as a dietary and therapeutic agent. Natural food takes a leading place in the diet of most of mankind. It was found that proper selection in the variety of vegetables and growing technologies not only provides the body with carbohydrates, fats, vitamins and minerals, but

* To whom all correspondence should be addressed. also supplies it with proteins that contain amino acids necessary for one's wellbeing.

Numerous studies have reported the importance of plant foods containing nearly all nutrient compounds, vital for human nutrition as well as a large number of health-promoting chemical substances ${ }^{1}$. For instance, amino acids, vitamins C and $\mathrm{B}$, and some plant secondary metabolites such as flavonoids, phenoloc acids, lignans, carotenoids, tocopherols and tocotrienols are essential for human body. Furthermore, some vegetables including carrots comprise high 
concentrations of those compounds ${ }^{1-3}$.

Carrot (Daucus carota L.) is one of the important vegetable that contains various amounts of beneficial substances, including ascorbic acid (vitamin C). It has been established that ascorbic acid hinders some illnesses such as cancer ${ }^{4-5}$, cardiovascular diseases ${ }^{6}$, high blood pressure, diabetes, and atherosclerosis ${ }^{7-9}$. Moreover, the carrot is a good source of carotenoids and its regular consumption is associated with a reduced risk of many chronic diseases ${ }^{10}$. Many studies have shown the positive correlation between high vegetable intake and decrease of some diseases. Therefore cultivation and regular consumption of the carrot and vegetables in general are of a major importance.

Regarding this challenge, the successful solution needs a sustainable base for agricultural production and food availability for the whole population of Kazakhstan. According to data from the Statistics Committee the total cultivated area of vegetables in the republic in 2015 was 137.7 thousand hectares with an average yield of 15-24 t/ha and gross yield of 3469.9 thousand tons. In the human diet a significant place is taken by the edible roots that account for $20-35 \%$ of all vegetables ${ }^{11}$.

The leading role belongs to carrot (Daucus Carota L.) - a valuable vegetable crop used in human food since ancient times. The norm of its consumption per person comprises $8.7 \mathrm{~kg}$ per year. This culture is characterized by high yield, steady quality and, of course, it is used in cooking, canning and drying. Carrots contain more than $14 \%$ of dry matter, $10 \%$ of carbohydrates and $10-15 \%$ of carotene $^{12}$. Among vegetable crops, carrot takes one of the leading places in Kazakhstan in terms of its sown area, and it is important to the diet of the population ${ }^{13}$. In Kazakhstan carrot sowings occupy an area of 20.2 thousand hectares with a gross yield of 523.2 thousand tons.

At the same time, the yield of vegetable crops in the country is still low. One of the main reasons is the lack of soil moisture due to an acute shortage of irrigational water. As has been reported, good quality watering is achieved only with the right choice of method and technique of irrigation, because irrigation regime, crop yields, labor productivity and volume of planning works largely depend on $\mathrm{it}^{14}$. In this aspect the application of water-saving technologies is important since the possible irrigated land of the country is about 2 million hectares. It also should be noted that in accordance with the relevant medical standards, $126 \mathrm{~kg}$ of various vegetables and $20 \mathrm{~kg}$ of melons have to be consumed by each Kazakhstan inhabitant annually, which requires an increase of the planted area and productivity through the use of different types of resource-saving irrigational technologies. Thus, there is a great potential for the introduction of water-saving technologies, including sprinkler irrigation systems. One such resource-saving irrigation method is finely dispersed irrigation or sprinkler irrigation. It aims at regulating the phyto-climate of soil and plants as well as meets the requirements of water conservation ${ }^{14}$. Sprinkler irrigation is not widely used in Kazakhstan yet and considered a relatively new method of watering which demonstrates the relevance of the research. In order to implement this technology at farms, the comprehensive study of the topic in the climatic conditions of Kazakhstan is needed.

\section{MATERIALSAND METHODS}

\section{Description of the experimental plot}

Research into the effect of sprinkler irrigation application during the growth season of carrot (Daucus carota L) was carried out on the experimental plots of the Kazakh scientific research institute of potato and vegetable growing located in the foothills of south-east Kazakhstan, on the northern slope of the Trans-Ili Alatau at an altitude of 950-1050 m above sea level. The soil of the experimental plots was dark chestnut, medium loamy, with undeveloped profile, clearly differentiated into genetic horizons. The topsoil contained $2.9-3.01 \%$ of humus; $0.18-0.20 \%$ of total nitrogen; $0.19-0.20 \%$ of total phosphorus and 2.4$2.7 \%$ of total potassium. The content of mobile phosphorus and potassium in the topsoil was 33$35 \mathrm{mg} / \mathrm{kg}$ and $340-360 \mathrm{mg} / \mathrm{kg}$, respectively. The reaction of the soil solution was slightly alkaline (pH 7.3-7.4). Soil bulk density was $1.1-1.2 \mathrm{~g} / \mathrm{cm}^{3}$, the lowest water capacity made up $26.6 \%$. Soil structure was loose and formed a dense crust during the irrigation or after rain, which broke its water and air regimes.

The local climate was sharply continental. 
The stable transition of air temperature over $0{ }^{\circ} \mathrm{C}$ in the spring took place at the end of second and at the beginning of third weeks of March; in the autumn - at the end of the first and at the beginning of the third weeks of November. The sum of the active temperatures was $3100-3400^{\circ} \mathrm{N}$. Spring frosts stopped in the third week of April, and were renewed in the autumn, in the third week of September or at the beginning of October. The average duration of the frost-free period comprised 140-170 days. The annual precipitation was $350-600 \mathrm{~mm}$ of which 250 $320 \mathrm{~mm}$ coincided with the warm period. The hydrothermal factor was 0.7-1.0.

\section{Equipment description}

The irrigation equipment used was from the Israeli company «Naan Dan Jain», which fully met the requirements for the quality and durability of products. All production processes matched the most stringent requirements of international quality standards (ISO 9001:2000). The developed system of sprinkler irrigation was performed with all the requirements of sustainability. The complete sprinkler system consisted of a polyethylene pipe with the diameter of $50 \mathrm{~mm}$ and was collected using 10-12 meter segments. Sprinkler model was 5022 SD; pressure - 3.5 bar; nozzle $-3.5 \mathrm{~mm}$; the water flow $-0.87 \mathrm{~m}^{3} / \mathrm{h}$; the diameter of the 1 sprinkler spraying $-12 \mathrm{~m}$.

\section{Biological materials}

On experimental plots, a local variety of the carrot Alau (Daucus carota L) was cultivated. Agricultural technologies were applied in accordance with the generally accepted recommendations of KazRIPVG in the piedmont area of south-east Kazakhstan.

\section{Analytical methods and parameters measured}

Studies were conducted in accordance with the classical methods, guidelines, recommendations and instructions ${ }^{15-18}$. Norms of vegetative watering were determined by moisture deficit in the soil between the upper limit of moisture content (field capacity) and the lower limit formula by I. A. Kostyakov: M = $100 \mathrm{~L}$ h(MWC - AM) CF where: $\mathrm{M}$ - irrigation norm, $\mathrm{m}^{3} / \mathrm{ha}$; $\mathrm{L}$ - soil bulk density, g/cm³ ; h-depth of wetting, m; MWC minimum water capacity,\%; AM - actual moisture before irrigation,\%; CF - correction factor of the accounting for water on evaporation and transpiration $(\mathrm{CF}=1)$. Accounting for irrigation water was carried out through a flood-free weir
"Chipoletti" with a threshold of $50 \mathrm{~cm}$ placed at the beginning and end of the experimental plot to measure the wastewater. The quality indicators of vegetable production were defined by the following methods: dry matter - according to the method of drying; total sugar - according to Bertrand; vitamin C and carotene - according to Murry; nitrates - potentiometrically using ionselective electrodes. The calculation of crop yield was done by a continuous method on each replication of field experience with the definition of the structure of the crop. Quantitative and gravimetric methods were used to control the field contamination. For example, the areas (constant for the period of experiments) of a certain size were allocated on experimental plots, where the number and wet weight of weeds in $1 \mathrm{~m}^{2}$ were determined. A commonly used method in the Republic of Kazakhstan "Guidelines for the registration tests of herbicides, defoliants, desiccants and plant growth stimulants” was applied ${ }^{19}$. Mathematical processing of the obtained data was conducted by the analysis of variance ${ }^{16}$.

\section{RESULTS AND DISCUSSION}

KazSRIPVG conducted studies to assess the fine irrigation system (sprinkler irrigation) of «NaanDaanJain» (Israel), a leading company in the sphere of water-saving technologies. Finely dispersed irrigation or sprinkler irrigation using sprinklers (spray sprinklers) is one of the main methods of irrigation in areas with uneven terrain and with an acute shortage of irrigational water. Field experiments concerned vegetables such as carrot. The influence of sprinkler irrigation on the conservation of irrigation water, contamination of the fields, productivity and quality of vegetable crops was studied.

\section{Conditions of growing}

Weather conditions in 2014 were characterized with a cold spring and a large amount of rainfall (133.5 mm - in April). Low temperatures for a long time and excess moisture in the soil had a negative effect on seedling emergence and development of early sown vegetables (carrots). At the same time, diseases developed. Prolonged cold and rainy spring gave way to hot summer period with high air temperatures (up to $35-37^{\circ} \mathrm{C}$ ) along with continuous absence (more than 2 
months) and a minimum amount of rainfall. So, from June to September a very small amount of precipitation fell, which differed significantly from the average long-term data. Hot weather with low relative humidity had a depressing effect on the growth and development of vegetable crops. The uneven distribution of rainfall during the growing season (April-September) is shown in the 2014 meteorological data (Table 1).
In turn, the weather conditions during the vegetable growing season of 2015 also differed somewhat from the long-term average data. These strong fluctuations of weather conditions were observed for several months. Thus, the average monthly air temperature in April was $4.5^{\circ} \mathrm{C}$, which meant 2 times lower than the average long-term data $\left(9.2^{\circ} \mathrm{C}\right)$. In May, June and September decreases in temperature compared to the long-term data on

Table 1. Meteorological data for the 2014-2015 seasons of growth

\begin{tabular}{|c|c|c|c|c|c|c|c|}
\hline \multirow[t]{2}{*}{ Periods } & \multicolumn{6}{|c|}{ The season of growth (months) } & \multirow{2}{*}{$\begin{array}{c}\text { The sum of (average) } \\
\text { during the } \\
\text { growing season }\end{array}$} \\
\hline & April & May & June & July & August & September & \\
\hline \multicolumn{8}{|l|}{ Temperature, ${ }^{\circ} \mathrm{C}$} \\
\hline 2014 & 10.02 & 17.34 & 22.03 & 25.5 & 22.6 & 15.2 & 18.8 \\
\hline 2015 & 4.15 & 11.02 & 15.2 & 29.6 & 23.75 & 14.3 & 16.3 \\
\hline Long-term data & 9.2 & 14.5 & 18.8 & 21.5 & 20.9 & 17.6 & 17.1 \\
\hline \multicolumn{8}{|c|}{ Relative humidity, \% } \\
\hline 2014 & 77.2 & 53.8 & 56.7 & 54.5 & 44.0 & 59.6 & 57.6 \\
\hline 2015 & 71.78 & 68.22 & 56.0 & 42.9 & 49.1 & 62.7 & 58.45 \\
\hline Long-term data & 66.03 & 61.0 & 55 & 49.2 & 57.0 & 57.0 & 57.9 \\
\hline \multicolumn{8}{|c|}{ Precipitation, mm } \\
\hline 2014 & 133.5 & 58.0 & 17.5 & 7.0 & 12.5 & 0.9 & 229.4 \\
\hline 2015 & 74.8 & 42.5 & 59.0 & 22.0 & 20.0 & 26.0 & 239.3 \\
\hline Long-term data & 90.6 & 81.2 & 57.7 & 21.8 & 17.5 & 22.1 & 288.0 \\
\hline
\end{tabular}

Table 2. Influence of sprinkler irrigation on the yield of carrots (2014-2015)

\begin{tabular}{|c|c|c|}
\hline \multirow[t]{2}{*}{ Irrigation technologies } & \multicolumn{2}{|c|}{ Research years } \\
\hline & 2014 & 2015 \\
\hline Furrow irrigation (control) & 25.2 & 26.4 \\
\hline Sprinkler irrigation & 28.3 & 30.7 \\
\hline \multirow[t]{2}{*}{ Harvest difference } & 3.1 & 4.3 \\
\hline & 12.3 & 16.3 \\
\hline $\mathrm{m}, \%$ & 2.32 & 3.03 \\
\hline $\mathrm{LSD}_{05}, \mathrm{t} / \mathrm{ha}$ & 2.07 & 2.88 \\
\hline
\end{tabular}

3.3-3. $6^{\circ} \mathrm{C}$ was also noted, and, on the contrary in July, there was a significant (by $8.1^{\circ} \mathrm{C}$ ) excess from $21.5^{\circ} \mathrm{C}$ to $29.6^{\circ} \mathrm{C}$. Relative humidity also varied considerably from the average long-term performance: in April - 71.8 and 66.0\%, in May 68.2 and $61.0 \%$, July -42.9 and $49.2 \%$ respectively.

The quantity of atmospheric precipitation was significantly lower compared to the average long-term data, similar to 2014. During the growing season there only $239 \mathrm{~mm}$ of rain fell, which was less than the average annual data (288 $\mathrm{mm}$ ) by

Table 3. Effect of irrigation technology on biochemical indices of production in 2014-2015

\begin{tabular}{|c|c|c|c|c|c|c|c|c|c|c|}
\hline \multirow{3}{*}{$\begin{array}{l}\text { Irrigation } \\
\text { technology } \\
\text { and period }\end{array}$} & \multicolumn{10}{|c|}{ Indicators } \\
\hline & \multicolumn{2}{|c|}{ Dry matter, \% } & \multicolumn{2}{|c|}{ Total sugar, \% } & \multicolumn{2}{|c|}{ Vitamin C, mg\% } & \multicolumn{2}{|c|}{ Carotene, mg\% } & \multicolumn{2}{|c|}{ Nitrates, mg } \\
\hline & $F I^{*}$ & $S I^{* *}$ & $F I^{*}$ & $S I^{* *}$ & $F I^{*}$ & $S I^{* *}$ & $F I^{*}$ & $S I^{* *}$ & $F I^{*}$ & $S I^{* *}$ \\
\hline 2014 & 12.73 & 12.82 & 8.65 & 9.0 & 9.95 & 8.7 & 16.49 & 16.7 & 86 & 144 \\
\hline 2015 & 12.20 & 15.08 & 10.0 & 9.5 & 9.4 & 9.5 & 16.5 & 17.30 & 93 & 85 \\
\hline
\end{tabular}

$\mathrm{FI}^{*}$ - furrow irrigation; SI** - sprinkler irrigation. 
$17 \%$. In April the amount of rainfall was $74.8 \mathrm{~mm}$, and in May $42.5 \mathrm{~mm}$, less than the average longterm data by 17.4 and $47.7 \%$, respectively. The least precipitation occurred in the spring. Inadequate rainfall was regulated by irrigation of vegetable crops.

In general, the weather conditions during the season of growth (April-September) in 2015 were relatively favorable for the cultivation of vegetable crops, while, 2014 turned out to be extremely unfavorable. During the vegetable growth season, the negative impact of unfavorable weather conditions on plant growth and development and on the formation of the vegetable crop yield was reduced through agricultural activities (watering, fertilizing, interrow handling, pest control, etc.).

Effect of sprinkler irrigation on the contamination of carrot fields and amount of irrigation water

Phytosanitary monitoring of vegetable crops showed that during sprinkler irrigation contamination of fields was markedly reduced. Compared to the furrow irrigation the number of weeds on the carrot fields was decreased by $38.27 \%$ in 2014. Fewer weeds were also detected in the received data in 2015 . So, the contamination of the carrot fields was decreased by $54.45 \%$ (Figure 1 ).

From these results, it should be noted the advantage of using the sprinkler irrigation. In experiments with carrots sprinkler irrigation has had a positive influence on the formation of vegetative biomass and edible parts of crops.

Thus, in this experiment variant, carrot plants were leafier, had greater overall weight that showed the positive influence of the finely dispersed irrigation. Therefore, plants have developed more intensively, formed more powerful biomass, thereby suppressing the growth of

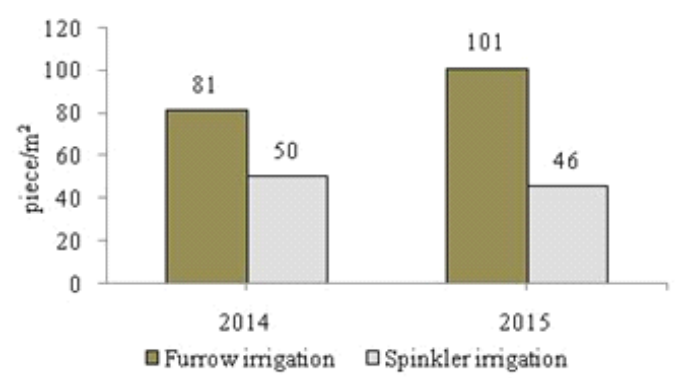

Fig. 1. Influence of sprinkler irrigation on the contamination of the carrot sowings (2014-2015) weeds. In addition, reducing the number of weeds was due to the supply of irrigation water, for instance, when watering overlap weed seeds spread everywhere contaminating the fields. Thereby it requires greater chemical and mechanical processing of the fields. The sprinkler irrigation significantly reduces the frequency of handling.

The slope of a foothill zone of the southeast of Kazakhstan is $3-5^{\circ}$. With traditional furrow irrigation percentage of nutrient washout from the soil is very high due to irrigation erosion ${ }^{20}$. As the results have demonstrated, the sprinkler irrigation could prevent this deterioration of agrophysical properties of the foothill dark brown soils. Soil compaction was decreased compared to the furrow irrigation: bulk density was 1.16 and $1.20 \mathrm{~g} / \mathrm{cm}^{3}$, the porosity of the soil -54.5 and $58.9 \%$ respectively. This ensures optimum water-air regime in soil for the root development and vegetative biomass of vegetables. Thus, the use of sprinkler irrigation has a positive effect on plant growth and development, on the formation of vegetative biomass and edible parts.

Meanwhile, studies on the consumption of irrigation water have shown that between two irrigation technologies there was a notable decrease in the cost of irrigation water due to the sprinklers used. Conservation of irrigational water is a significant indicator of the effectiveness of water-saving technologies. Therefore, the measurements on the plants water consumption were carried out.

In 2014 while under furrow irrigation the carrot crop used $3700 \mathrm{~m}^{3} / \mathrm{ha}$ of water during the growing season, whereas under sprinkler irrigation the water used was $3040 \mathrm{~m}^{3} / \mathrm{ha}$ (Figure 2). Saving of water for the irrigation season of carrot consisted 660 $\mathrm{m}^{3} /$ ha or by $17.84 \%$.

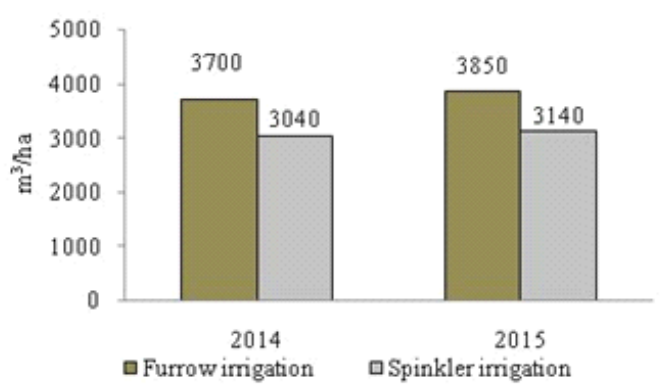

Fig. 2. Influence of sprinkler irrigation on conservation of irrigated water on carrot fields, $\mathrm{m}^{3} / \mathrm{ha}(2014-2015)$ 
Correlation of two factors: "irrigation system""crop yield and quality"

In irrigated horticulture, great attention is paid to the productivity of vegetable plantations. Each hectare of irrigated land is very important, especially in the foothills of south-east Kazakhstan. Therefore breeding research and technological development mainly focus on increasing the productivity of vegetable crops. The main indicator for the assessment of new technological developments in horticulture has always been the yield of vegetable crops. According to the research conducted, sprinkler irrigation technology provided a significant increase in the productivity of vegetable crops. Finely dispersed irrigation compared with furrow irrigation helped to improve the yield of carrots by $12.3 \%$ and $16.3 \%$ in 2014 and 2015, respectively (Table 2).

The value of the final harvest of vegetables has a close relationship with the habitus of plants. The stronger growth of plants leads to the higher productivity. Plants with strong development of biomass are more resistant to diseases and pests and suppress weeds. They have better developed photosynthetic activity that produces high yields of environmentally friendly vegetables with high quality indicators due to the exclusion or minimization of chemical treatments against pests. As has already been mentioned, finely dispersed irrigation contributes to a more powerful plant growth and development in comparison with the conventional method of furrow irrigation. Therefore, development of vegetable plants has a very important agroeconomic and environmental meaning.

Since vegetables are important sources of vitamins, minerals, micronutrients, carbohydrates, biologically active substances, as well as dietary fiber needed to full and balanced diet, yields of vegetable crops should be environmentally friendly and safe. In this regard the biochemical analyzes of the vegetable crops on the determination of their quality have been carried out at the laboratory of mass analysis of KazSRIPVG. Consequently, the positive impact of sprinkler irrigation technology on the biochemical indicators of vegetable crops should be highlighted (Table 3). The amount of dry matter, vitamin $\mathrm{C}$ and carotene carrots contain have all increased.
Particular attention should be paid to enhanced amount of carotene, for which the carrot is valued. In 2014, while sprinkler irrigation the carotene content (provitamin A) in the edible parts raised from $16.49 \mathrm{mg} \%$ to $16.7 \mathrm{mg} \%$. In 2015, these rates varied from $16.5 \mathrm{mg} \%$ to $17.3 \mathrm{mg} \%$. Dry matter content increased up to $15.08 \%$. The nitrate content in carrot roots according to the irrigation methods was 86 and $144 \mathrm{mg}$ per $1 \mathrm{~kg}$ of wet weight in 2014, and 93 and $85 \mathrm{mg} / \mathrm{kg}$ in 2015. If one considers that acceptable levels of nitrates in carrot is $400 \mathrm{mg} / \mathrm{kg}$ of wet weight ${ }^{21}$ then the product can be considered as environmentally friendly.

\section{CONCLUSION}

The leading countries of the world use finely dispersed irrigation on large areas. In the Republic of Kazakhstan sprinkler irrigation is relatively new and not widely used yet. Before recommending and implementing the technology of sprinkler irrigation it is necessary to comprehensively study and determine its agronomic, economic and environmental efficiencies. Therefore, our research has focused on the impact of fine sprinkling irrigation on the main indicators of the productivity of vegetable crops such yield and quality, as well as the amount of irrigation water used and the contamination of the fields. So, there was a positive impact of finely dispersed irrigation technology on the water conservation up to $18.44 \%$ during irrigation of the carrots. Contamination of fields has decreased by $38.27 \%$ to $54.45 \%$ for each respective research year. The most important indicator such as crop yield also has increased compared to the traditional method of watering. Sprinkler irrigation technology contributed to the additional 3.1-4.3 tons of crops from 1 hectare.

Thus, a relatively new kind of irrigation for the country - finely dispersed irrigation technology using sprinklers has certain advantages over traditional furrow irrigation, and is promising for irrigated vegetable production in Kazakhstan. Studies showed that the sprinkler irrigation demonstrates high efficiency and has great prospects in the conditions of a foothill zone of south-eastern Kazakhstan. 


\section{REFERENCES}

1. Hounsome N, Hounsome B, Tomos D, Edwards-Jones G. Plant Metabolites and Nutritional Quality of Vegetables. J Food Sci., 2008; 73(4):R48-65. doi: 10.1111/j.17503841.2008.00716.x.

2. L.A. Castro-Concha, J. Tuyub-Che, A. MooMukul, F.A. Vazquez-Flota, and M.L. MirandaHam. Antioxidant Capacity and Total Phenolic Content in Fruit Tissues from Accessions of Capsicum chinense Jacq. (Habanero Pepper) at Different Stages of Ripening. The Scientific World Journal; 2014; 195: 809073. DOI: $10.1155 / 2014 / 809073$. Date Views 22.01.2015

3. Ghasemnezhad M., M. Sherafati, G.A. Payvast.Variation in phenolic compounds, ascorbic acid, and antioxidant activity of five coloured bell pepper (Capsicum annum) fruits at two different harvest times. Journal of Functional Foods, 2011; 3:44-49.

4. Raymond Y.C., C.S. Glenda, L.K.Meng. Effects of High Doses of Vitamin C on Cancer Patients in Singapore: Nine Cases. Integr.Cancer Ther. Dec 2015; 17. pii: 1534735415622010. Date Views 22.01.2015.

5. Reczek C.R., N.S Chandel. CANCER. Revisiting vitamin C and cancer.Science, 2015; 11: 350(6266): 1317-8. doi: 10.1126/science. aad8671.

6. Diane L. Tribble Antioxidant Consumption and Risk of Coronary Heart Disease: Emphasis on Vitamin C, Vitamin E, and b-Carotene. A Statement for Healthcare Professionals for the American Heart Association.Circulation, 1999; 99: 591-595doi: 10.1161/01.CIR.99.4.591

7. Overview. Vitamin C (Ascorbic acid). Date Views 25.01.2016 umm.edu/health/medical/ altmed/supplement/vitamin-c-ascorbic-acid.

8. Jamalan M., M. Rezazadeh, M. Zeinali, M.A. Ghaffari. Effect of ascorbic acid and alphatocopherol supplementations on serum leptin, tumor necrosis factor alpha, and serum amyloid A levels in individuals with type 2 diabetes mellitus. Avicenna J Phytomed, 2015; 5(6):531539.

9. Price K.D., Price C.S., Reynolds R.D., Hyperglycemia-induced ascorbic acid deficiency promotes endothelial dysfunction and the development of atherosclerosis. Atherosclerosis, 2001; 158(1):1-12.
10. Huck, C.W., M. Popp, H. Scherz and G.K. Bonn, Development and Evaluation of a New Method for the Determination of the Carotenoid Content in Selected Vegetables by HPLC and HPLCMS-MS. Journal of Chromatographic Science, 2000; 38(10): 441-449 Date Views 22.01.2016 oxfordindex.oup.com

11. Storage of edible roots. Recommendations of Kazakh scientific research institute of potato and vegetable growing, 2012; 16

12. Schepetkov N.G., N.Zh. Zhanbyrshina, Economic assessment of growing seeds of edible roots depending on farming practices. Materials of the Republican scientific-theoretical conference "Seyfullin readings-11: Youth and Science”. 2015. T.², pp: 85-89.

13. Amirov B., Udovitskiy A., Zh. Amirova, Ecological testing of carrot varieties from Taiwan in northern Kazakhstan. Scientific papers of the Institute of Bioenergy Crops and Sugar Beet: Collected articles, 2014; 21: 148-151

14. Grigorov, M.S., S.M. Grigorov and M.V. Demkov. Irrigation methods and modes of crops irrigation in different regions. In the Proceedings of the Anniversary International Scientific and Practical Conference (Kostyakovsky reading): Problems of sustainable development of land reclamation and environmental management, 2007; 1: 143-150. Volgograd State Agricultural Academy www.cawater-info.net

15. Yudin F.A. Agrochemical Research Methods. Moscow, 1980; 366.

16. Dospehov B.I., Methods of field experience. Moscow, 1985; 420

17. The methodology of experimental work in the vegetable and melon growing. Ed. V.F. Belik. Moscow, 1992; 320.

18. Guidelines for determination of nitrate in crop production. Moscow, 1986; 45.

19. Guidelines for the registration tests of herbicides, defoliants, desiccants and plant growth stimulants. Almaty-Akmola 1997; 32

20. Rakhymzhanov B.S., Agroeconomic and ecological efficiency of a drip irrigation of vegetable crops in the south-east of Kazakhstan: thesis for the degree of Ph.D, 2015; 49-54.

21. Buribayeva L.A., Krasavina V.K., Yelikbayev B., M.B. Zhakashbayeva, Nitrate accumulation in edible roots according to their varietal characteristics and mineral nutrition. News of the National Academy of Sciences of the Republic of Kazakhstan, 2014; 5(23): 36-41. 